Agnieszka Kisztelińska-Wegrzyńska

Łódź

\title{
DZIAŁALNOŚĆ AUSTRIACKIEGO FORUM KULTURY W KONTEKŚCIE WSPÓŁCZESNYCH RELACJI POLSKO-AUSTRIACKICH
}

\section{Wstęp do współczesnych relacji polsko-austriackich}

Polska była pierwszym krajem bloku wschodniego, z którym Austria rozpoczęła $\mathrm{w}$ połowie lat sześćdziesiątych $X X$ wieku znaczącą współprace kulturalną. Zaangażowano wówczas grupę osób odpowiedzialnych za przygotowanie stosownych umów i powołanie do życia Instytutu Kultury w Warszawie funkcjonującego do dziś pod zmienioną nazwą - Austriackie Forum Kultury. Historia owego Instytutu to jednocześnie istotny fragment polsko-austriackich stosunków kulturalnych.

Opisując podstawy najnowszych relacji polsko-austriackich należy zwrócić uwagę na wspólne cele polityki zagranicznej wyznaczone przez te państwa współdziałające na forum Unii Europejskiej. Austria zajmuje istotne miejsce $\mathrm{w}$ gronie państw europejskich $\mathrm{z}$ którymi Polska utrzymuje poprawne, oparte na zasadzie wzajemnych korzyści relacje. Tendencja do zacieśnienia tychże kontaktów widoczna w danych statystycznych pozytywnie rokuje $\mathrm{w}$ najbliższej przyszłości ${ }^{1}$. Stałym i ważnym elementem poprawnej współpracy jest bogata i barwna wymiana na poziomie kultury i nauki, z której owoców korzystają obydwa narody. Ważną rolę we wzajemnych relacjach odgrywa kultura. W Polsce, uważanej za kulturowego sąsiada, Austria jest reprezentowana przez wiele austriackich

1 Zob. D. Popławski, Austriacka polityka neutralności 1955-1995, Warszawa 1995, A. Kisztelińska-Węgrzyńska, Austria w dyplomacji polskiej po 2004 roku, [w:] Polityka-kultura-społeczeństwo. Niemcy, Austria, Szwajcaria w pierwszej dekadzie XXI wieku, pod red., E. Kuczyńskiego, M. Tomczyka, Łódź 2013, s. 120-133. 
instytucji kultury w Warszawie, Krakowie, Opolu, Przemyślu, Poznaniu i Wrocławiu

Wśród najważniejszych wydarzeń kulturalnych w ostatnich kilkunastu latach wymienić należy te organizowane w ramach promocji wiedzy na temat kultury polskiej przed przystąpieniem naszego kraju do UE. Zorganizowano wówczas szereg uroczystości pod wspólnym hasłem Rok Polski w Austrii. Odbył się on na przełomie 2002-2003 roku w wyniku porozumienia zawartego między Ministrami Spraw Zagranicznych naszych państw. Realizowany był głównie przez Instytut Adama Mickiewicza we współpracy z Instytutem Polskim w Wiedniu, Ambasadą Polską w Wiedniu, Muzeum Narodowym w Warszawie, Zamkiem Królewskim w Warszawie. Projekt był częścią rządowego „Ramowego programu promocji zagranicznej akcesji Polski do Unii Europejskiej”. Patronat honorowy nad Rokiem Polskim w Austrii objęli Prezydent Republiki Austrii Thomas Klestil i Prezydent Rzeczpospolitej Polskiej Aleksander Kwaśniewski. Była to największa promocja polskiej kultury za granicą w 2002 roku, obejmowała ponad 120 wydarzeń kulturalnych prezentowanych w muzeach, galeriach, salach koncertowych Wiednia, Linzu, Grazu, Salzburga i Innsbrucku. Wielkim zainteresowaniem cieszyły się spotkania z polskimi pisarzami.

Wszystkie wieczory autorskie odbywały się przy pełnych salach. W sumie wzięło w nich udział około 2 tys. osób. Z austriackimi czytelnikami spotkali się m.in. Ewa Lipska, Adam Zagajewski, Paweł Huelle, Ewa Kuryluk, Andrzej Stasiuk, Michał Głowiński, Piotr Sommer, Olga Tokarczuk, Krzysztof Varga, Daniel Odija oraz Hanna Krall. „Literatur und Kritik" zamieściło teksty Krzysztofa Vargi, Andrzeja Stasiuka, Ryszarda Kapuścińskiego oraz teksty tłumacza i slawisty Martina Pollaka. W programie muzycznym najbardziej interesujące dla Austriaków okazały się koncerty jazzowe. Wysłuchało ich prawie 4 tys. osób. Na JazzFestWien i w popularnym klubie Porgy\&Bess zagrali m.in. Urszula Dudziak, Zbigniew Namysłowski, Kuba Stankiewicz, Tomasz Stańko. Stańko uhonorowany został Europejską Nagrodą Jazzową im. Hansa Kohlera, którą po raz pierwszy wręczono $\mathrm{w}$ tej kategorii.

Wyrazem ścisłych kontaktów między naszymi krajami jest Polsko-Austriacka Nagroda. Została ufundowana w 2001 r. przez ministrów spraw zagranicznych Polski i Austrii jako polsko-austriacka nagroda dziennikarska, a następnie w roku 2005, przekształcona w Nagrodę na Rzecz Rozwoju Stosunków Polsko-Austriackich².

${ }^{2}$ Jej celem jest pogłębianie wzajemnego zrozumienia i współpracy między Polską i Austrią. Nagroda jest przyznawana raz w roku zamiennie - to polskim to austriackim dziennikarzom, przedstawicielom świata kultury, naukowcom i innym osobom z Polski 
Od czasu podpisania umowy o wymianie kulturalnej i naukowej z 1968 roku, rozwija się nieprzerwanie wymiana na poziomie uczelni wyższych. Lektorzy austriaccy pracują na uniwersytetach w Toruniu, Krakowie, Łodzi, Poznaniu, Warszawie i Wrocławiu.

Wśród inicjatyw kulturalnych które wyróżniają się na tle działań popularyzujących wymianę austriacko-polską należy wymienić działalność Forum Kultury Austriackiej w Warszawie. Celem działań w ostatnich latach jest zacieśnienie współpracy z polskimi instytucjami partnerskimi spoza stolicy. Blisko 200 imprez kulturalnych rocznie odbywa się właśnie poza Warszawa, aby w uboższych regionach talenty również miały szanse rozwoju.

\section{Współczesne badania polskie na temat współpracy kulturalnej z Austrią}

Analizując tematykę polsko-austriackich powinowactw kulturowych można wyodrębnić trzy zasadnicze obszary. Pierwszym jest Polonia i Polacy w dziejach Austrii, drugi - powiązania literackie, natomiast trzeci to dzieje społeczne Republiki Austriackiej, wespół z odniesieniami do historii najnowszej. Biorąc pod uwagę ten podział wśród najważniejszych publikacji jakie ukazały się w Polsce po 2000 roku wymienić należy w kolejności chronologicznej choćby: W.S. Kucharski, Polacy i Polonia w Austrii. Część I, Zasłużeni; A. Nadolny, Polskie duszpasterstwo w Austrii po II wojnie światowej 1945-2001, Niemcy, Austria, Polska w XIX i XX wieku, pod red. T. Dubickiego, K.A. Kuczyńskiego; A. Pilch, Studia młodzieży polskiej w Austrii 1919-1980; B. Sturzbecher, Bibliografia przekładów literatury austriackiej na język polski z lat 1945-2000; R. Taborski, Polacy w Wiedniu, Z zagadnień współpracy polsko-austriackiej, pod red. Z. Tomkowskiego, S. H. Kaszyński, Krótka historia literatury austriackiej, tego samego autora również $W$ cieniu habsburskich krajobrazów. Trzynaście esejów o kulturze austriackiej, E. Hurnikowa, W kręgu wiedeńskiej moderny. Z zagadnień polsko-austriackich powinowactw kulturowych, E. Białek, K. Nowakowska (red.) Literatura austriacka w Polsce w latach 1980-2010. Szkice do historii recepcji. Z analizy publikacji jakie ukazują się współcześnie w Polsce a dotyczą polsko-austriackich relacji kulturalnych wynika, iż stale utrzymuje się widoczne zainteresowanie wspólnymi korzeniami historycznymi i kulturowymi z naciskiem na recepcję literatury i ocenę dorobku Polonii mieszkającej w Austrii.

\footnotetext{
i Austrii, które swoją działalnością wspierają stosunki między naszymi krajami. O przyznaniu nagrody decyduje jury, w którego skład wchodzą ambasadorowie RP w Austrii w Polsce oraz znane polskie i austriackie osobistości ze świata mediów, kultury, gospodarki i nauki.
} 


\section{Historia Instytutu Kultury w Warszawie - „Czytelni Austriackiej"}

Historia Instytutu Kultury w Warszawie sięga 1962 roku kiedy to strona polska zaproponowała adaptację budynku na ulicy Próżnej w Warszawie tzw. "pawilonu” usytuowanego w centrum miasta pomiędzy instytucjami naukowymi Uniwersytetu. Modernizacji budynku podjął się austriacki architekt Carl Aubock, który w 1963 roku pracował również nad siedzibą Instytutu Kultury w Nowym Jorku. Prace ukończono w 1964 roku. W pierwszych raportach dotyczących działalności Instytutu gromadzonych w austriackim Ministerstwie Szkolnictwa pisano o sukcesie jaki odniosła ta placówka przyciągając intelektualne grupy młodzieży i elitę Polski ${ }^{3}$. Otwarcie Instytutu poprzedziła inauguracja pracy Czytelni Polskiej w Wiedniu w 1961 roku. Obydwa te wydarzenia odbyły się bez rozgłosu i udziału mediów. Minister edukacji Theodor Piffl-Percević wydał w Warszawie przyjęcie 19 marca 1965 roku, aby uświetnić początki „Czytelni Austriackiej” jak zaczęto nazywać Instytut. Zrezygnowano jednak $\mathrm{z}$ wystąpień i programu artystycznego w duchu tzw "dyskretnego startu" ${ }^{4}$. Najważniejszym celem jaki założono wówczas miało być stworzenie miejsca do spotkań służących wymianie myśli bez względu na to z jakiego systemu politycznego się wywodzą rozmówcy. Ówczesny ambasador Kurt Enderl z satysfakcją odnotował, iż podczas inauguracji wśród siedmiuset zaproszonych gości byli min. Leszek Kołakowski, Zbigniew Herbert, Tadeusz Konwicki, Tadeusz Mazowiecki, Władysław Bartoszewski, Stefan Kisielewski, Stanisław Jarzy Lec, Stanisław Stomma czy Witold Wirpsza ${ }^{5}$.

Jednym z najistotniejszych aspektów działalności kulturotwórczej Instytutu była praca biblioteki. Propagowano literaturę niemieckojęzyczną i najnowsze badania przygotowywane w tym języku za granicą. Nierzadko sprowadzano książki dla potrzeb naukowych Uniwersytetu lub jak pisze Alexander Burka przechowywano „wyjątkowe książki dla wyjątkowych czytelników" ${ }^{\prime \prime}$. Drugim aspektem prac placówki było prowadzenie kursów języka niemieckiego już od stopnia podstawowego, cieszących się

${ }^{3}$ A. Burka, "Zabrać się do pracy rozważnie, zachować samokontrolę i wrażliwość". Poczatki Austriackiego Instytutu Kultury przy ulicy Próżnej 8 w roku 1965 [w:] Ulica Próżna i dzielnica żydowska w Warszawie, Próżna Strasse und das Judische Stadtviertel in Warschau, pod red. R. Chwiszczuk, Warszawa 2013, s. 184.

${ }^{4}$ A. Burka, Zabrać..., s. 184.

5 A. Burka, Co pozostało z okna na Zachód ? Polityka kulturalna Austrii w Europie Wschodniej od roku 1945 na przykładzie Polski i Czechosłowacji/Czech, red. H. Kramer i E. Kreisky, Reihe Politik und Demokratie, nr 23, Frankfurt nad Menem, Wiedeń 2012, s. 152.

6 A. Burka, Zabrać..., s. 186. 
dużym zainteresowaniem wśród społeczności Warszawy. Na tym polu Instytut skutecznie konkurował z placówkami wschodnioniemieckimi.

Udział ludności polskiej w działalności Instytutu wiązał się z koniecznością zachowania ostrożności. Jednakże z grona placówek zbliżonych profilem działalności do Instytutu a powstałych w krajach demokracji ludowej „Czytelnia” na Próżnej cieszyła się rosnącym zainteresowaniem i olbrzymią renomą. Przełom roku 1989 przyniósł zmiany również w zakresie celów i działań Instytutu. Alexander Burka austriacki badacz polityki kulturalnej Austrii na Wschodzie zwrócił uwagę na współczesną misję placówki mieszczącej się w granicach byłego getta warszawskiego. Historia najnowsza Austrii zobowiązuje do udziału w wydarzeniach upamiętniających tematy żydowskie, dlatego więc ta instytucja rokrocznie bierze udział w Festiwalu Kultury Żydowskiej - Warszawa Singera ${ }^{7}$.

Według polskiego publicysty Adama Krzemińskiego, który w czasach początkowej działalności „Czytelni Austriackiej” był studentem filologii germańskiej, placówka na Próżnej była miejscem ważnym i wyjątkowym. Do czasu zawarcia układu o normalizacji stosunków z RFN było to jedyne miejsce dla osób zainteresowanych kulturą niemieckojęzyczną z dostępem do prasy i nowości wydawniczych. Dzięki działalności austriackiej instytucji, środowiska polskich twórców odkrywały wielkich Austriaków - Doderera, Brocha, Musila, Strindberga i Arthura von Schnitzlera ${ }^{8}$. Wiedeń początków lat -70 tych postrzegano w Polsce jako miasto awangardy. Gunter Nenning, Otto Schulmeister, Paul Ledvai i Gyorgy Sebestyen komentowali na łamach austriackiej prasy najważniejsze wydarzenia polityczne i kulturalne zarówno Wschodu jak i Zachodu.

Lata osiemdziesiąte przyniosły podwójny kryzys. Wprowadzenie stanu wojennego utrudniło dotychczasową współpracę a afera Waldheima wyrobiła w polskiej opinii przekonanie, iż poszukiwanie dróg pośrednich w dążeniu do demokracji zachodnich należy zastąpić innymi działaniami. Rok 1989 przekonał Europę, iż Polska była promotorem przemian politycznych. Dla relacji polsko-austriackich był to początek nowego etapu. „Czytelni Austriackiej” nie postrzegano już wyłącznie jako „okna na świat". W ekspansji politycznej i kulturalnej rozpoznano nowe istotne obszary reanimując politykę wschodnia, promowaną od dziesięcioleci choćby przez paryską Kulturę. Jednocześnie po podpisaniu traktatu o dobrym sąsiedztwie punkt ciężkości spraw związanych z tematami niemieckimi przeniósł się do Ambasady RFN a także do Instytutu Goethego. Upadek żelaznej kurtyny przyniósł także konieczność redefinicji pozycji Austrii

\footnotetext{
7 A. Burka, Zabrać..., s. 188.

8 A. Krzemiński, Austriackie Forum Kultury w Warszawie od swoich początków do dzisiaj, [w:]Ulica Próżna i dzielnica żydowska w Warszawie, Próżna Strasse und das Judische Stadtviertel in Warschau, pod red. R. Chwiszczuk, Warszawa 2013, s. 190.
} 
w jednoczącej się Europie. Postrzeganie obywateli bloku wschodniego jako zagrożenia - taniej siły roboczej i narastające nastroje ksenofobiczne w drugiej połowie lat 90 . musiały przynieść negatywne skutki dla dotychczasowej współpracy kulturalnej Polski i Austrii. Jak pisze Adam Krzemiński: „Andreas Stadler, rzutki dyrektor Austriackiego Forum Kultury w latach 1999-2004, boleśnie odczuł ten chłodny wiatr końca lat 90., kiedy to z Wiednia dochodziły głosy ksenofobów skupionych wokół Jörga Heidera, a z Warszawy - żądania odszkodowań dla ofiar pracy przymusowej również na terenie Austrii" ${ }^{9}$. Dyrektor Stadler przełamał jednak złą passę i doprowadził do nawiązania współpracy z instytucjami partnerskimi, wspierającymi promocję kultury austriackiej. Spotkania z Robertem Menasse czy Antonem Pelinką cieszyły się dużym zainteresowaniem i przyciągały współczesne elity stolicy.

Ważną restrukturyzację przeszedł Instytut w 1997 roku. Wydzielono wówczas część zajmującą się nauczaniem języka niemieckiego powierzając to zadanie Österreich Institut z siedzibą w Warszawie, Krakowie i Wrocławiu. Odpowiedzialne zadanie promocji kultury i wiedzy o współczesnej Austrii przypadło w udziale AFK, działającego oficjalnie pod tą nazwą od 2001 roku.

Na równi z nowymi celami strategicznymi demokratycznego państwa polskiego rozwijały się prace na rzecz integracji ze strukturami europejskimi. Partycypacja Austrii i Polski w Unii Europejskiej wyznaczyła współczesne zadania Austriackiego Forum Kultury, którego zmieniona w 2001 roku formuła wspaniale wpisuje się w europejski dialog na rzecz zarówno promocji wspólnego dziedzictwa jak i współczesnej kultury wysokiej $^{10}$. Zarówno Austria jak i Polska skupiają się obecnie na poszukiwaniu swej regionalnej roli, a także tożsamości kulturowej. Wspólne tematy i pytania, jakie rodzą się w związku z tym zbliżają obydwa narody.

\section{Współczesne płaszczyzny działania Austriackiego Forum Kultury}

W ostatnich latach Austriackie Forum Kultury zorganizowało lub wzięło czynny udział w setkach imprez kulturalnych na terenie całej Polski. Sympozja na temat najbardziej palących problemów Europy: ludzi

${ }_{9}$ Cyt za: A. Krzemiński, op. cit., s. 194.

${ }^{10} \mathrm{~J}$. Anders, M. Hereźniak, Komercjalizacja elementów kultury narodowej jako narzędzie budowania międzynarodowego wizerunku kraju, [w:] Marketing kultury. Nowe wyzwania oraz nowe kierunki działania, pod red. T. Domańskiego, Łódź 2008, s. 69-79. Por. Instytucje kultury w czasach kryzysu, pod red. J. Sójka, D. Kliszewski, P. Landsberg, M. Popławski, Poznań 2009. 
wykluczonych i dyskryminowanych z powodów ekonomicznych, etnicznych czy orientacji seksualnej. Partnerzy tych przedsięwzięć cenią Forum jako miejsce otwartych spotkań i dyskursu. Wśród kluczowych celów przyjętych przez kierownictwo forum znajdowały się „,[...] inicjowanie i sponsoring imprez artystycznych i naukowych organizowanych przez Polskę i Austrię, przy czym uwzględnienie innych kultur w uznaniu globalnych powiązań w sztuce i nauce jest nie tylko możliwe, ale wręcz pożądane, a także przez współpracę z Bibliotekami Austriackimi w Krakowie, Opolu, Poznaniu, Przemyślu, Wrocławiu i Warszawie, z lektorkami i lektorami austriackimi w Krakowie, Łodzi, Poznaniu, Toruniu, Wrocławiu i Warszawie jak również z Instytutem Austriackim w Krakowie, Wrocławiu i Warszawie (kursy jęz. niemieckiego)"11.

Obecny zespół to mała ale energiczna grupa licząca kilka osób na czele z powołanym w 2013 roku dyrektorem Martinem Meiselem. Opisywana w poniższym tekście działalność była w dużej mierze zasługą poprzednich władz, pani dyrektor Ulli Krauss-Nussbaumer i pracujących również obecnie pań: Ernestine Baig, Agnieszki Borkiewcz, Andrei Brzozy, Natalii Wawrzewskiej i Jolanty Żukowskiej, ponadto w zespole działają jeszcze Gerald Eidherr i Jacek Malinowski ${ }^{12}$. Choć jest to niewielkie grono dokonania były i są znaczące. Wśród najważniejszych płaszczyzn działalności AFK w ramach promocji kultury austriackiej bądź działań dwustronnych wymienić można: naukę, film, literaturę, muzykę, teatr, sztuki wizualne, taniec.

W ciągu ostatnich pięciu lat zorganizowano kilkanaście wydarzeń artystycznych prezentujących dorobek kina austriackiego i europejskiego. Pracownicy Forum z radością informują swych sympatyków o przejawach zainteresowania i uznania dla kinematografii austriackiej w Polsce. Jessicka Hausner zdobyła w 2009 roku pierwszą nagrodę na Warszawskim Festiwalu Filmowym za „Lourdes“. Obecność przeglądu kina austriackiego na festiwalu Plus Camerimage w 2010 były również wyraźnym sygnałem, że film austriacki doceniony został przez polską publiczność. Austriackie Forum Kultury we współpracy z Instytutem Austriackim od lat zaprasza na wieczory filmowe w oryginalnej wersji językowej. Wśród wielu projekcji z ostatni lat wymienić można choćby pokaz filmu dokumentalnego „Leila i Lena" w reżyserii Michaela Pfeifenbergera dotyczącego przyjaźni kobiet w obliczu konfliktu bliskowschodniego; "Czym jest demokracja ?" Oliviera Resslera - jednego z bardziej znanych „,artystów zaangażowanych”, prezentowana we współpracy z Instytutem Sztuki - Wyspa w Gdańsku;

${ }^{11}$ Cytat za Austriackim Forum Kultury, http://www.austria.org.pl/NEW/PL/onas. php, [dostęp 21.01.2014]

${ }_{12}$ Na temat pracowników Forum http://www.austria.org.pl/NEW/PL/onas/zespol. php [dostep 21.01.2014] 
Wykład Evy Badury-Triski Rola filmu w akcjonizmie wiedeńskim połączony z prezentacją prac video mający miejsce również w Gdańsku w 2011 roku; prezentacja kina austriackiego w ramach VIII Festiwalu "Planet Doc", w warszawskiej Kinotece w maju 2011 roku; IFF Tofifest 2012 - prezentacja filmów awangardy austriackiej - Ulricha Seidla, Michaela Glawoggera, Marie Kreutzer, Barbary Eder, Götz Spielmanna i Markusa Schleinzera ${ }^{13}$. Wśród ważniejszych wydarzeń filmowych 2013 roku wymienić można konferencję organizowaną przy udziale Łódzkiej Szkoły Filmowej - Filmteractive Conference. Ta międzynarodowa konferencja, której tematem przewodnim są rozwiązania second screen, to jednocześnie pierwsze targi interaktywne i crossmedialne stworzone z myślą o twórcach, którzy chcą pokazać swój innowacyjny projekt przed międzynarodowym gronem content buyerów, przedstawicieli największych stacji telewizyjnych w Europie i ekspertów audiowizualnych ${ }^{14}$.

Obecnie we współpracy z polskimi galeriami sztuki i teatrami, Forum organizuje prezentacje współczesnej austriackiej twórczości artystycznej i literackiej. Przeniesienie Czytelni Austriackiej do nowej warszawskiej Biblioteki Uniwersyteckiej przybliżyło zasoby książkowe dawnej czytelni germanistyki. Austriackie Forum Kultury w Warszawie stawia sobie za cel ukazywanie rozwoju literatury austriackiej, wskazywanie na jej korzenie i związki z Polską w przeszłości i teraźniejszości a przede wszystkim prezentację twórczości współczesnych pisarzy austriackich w Polsce. Promocja literatury austriackiej i niemieckojęzycznej jest w zasadzie najbardziej widocznym elementem działalności forum. Raz bądź dwa razy w tygodniu odbywają się spotkania zarówno cykliczne, jak i okazjonalne, dla szerszej publiczności. Do stałych spotkań zaliczyć można wieczory autorskie (min. z Evelyn Grill, Lilian Faschinger, Evelyn Schlag, Eriką Fischer, Heinzem Nussbaumerem, Martinem Pollackiem, Radkiem Knappem, Arno Geigerem, Norbertem Gstreinem), ponadto „Przeczytane w tłumaczeniu”, „Rozmowy o literaturze niemieckojęzycznej”, czy „Próby czytania sztuki". W samym tylko 2013 roku Forum zorganizowało ponad trzydzieści wydarzeń promujących literaturę austriacką ${ }^{15}$.

${ }^{13}$ Forum pośredniczy także w wymianie muzyków orkiestr z obu krajów i ułatwia udział austriackich reżyserów w polskich pokazach filmowych: Plus Camerimage, Warsaw Filmfestival, TOFFI Festival Toruń czy Cinergia in Łódź.

${ }^{14}$ Filmteractive Festival to część poświęcona twórcom najciekawszych i najbardziej innowacyjnych projektów filmowych, crossmedialnych oraz interaktywnej sztuki cyfrowej. Gośćmi AFK byli: Arseny Vesnin (Designcollector, Rosja), Dawid Marcinkowski i Kasia Kifert / The Kissinger Twins (Wielka Brytania/Polska, laureaci Webby Awards 2013 za najlepsze wideo interaktywne), oraz dr Christa Sommerer i Laurent Mignonneau (Austria), www.filmteractive.eu/speakers.php [dostęp21.01.2014]

15 W zakładkach książki i autorzy, AFK prezentuje dorobek i sylwetki promowanych pisarzy, także, tych mniej znanych polskim czytelnikom. Znajduje się tam ponad pięć- 
AFK stawia sobie również za cel łamanie stereotypów na temat kojarzenia Austrii wyłącznie z muzyką poważną i klasyczną. Wspieranie innowacyjnych projektów muzycznych, jak np. prezentacja współczesnych kompozytorów austriackich, organizacja koncertów z różnorodną muzyką jazzową - od etno po alternatywna, jak i nowej muzyki improwizowanej i elektronicznej zajmuje ważne miejsce w działalności Forum. Dlatego na zaproszenie AFK do Polski przyjeżdżają wysokiej klasy, najczęściej młodzi, austriaccy muzycy. Występują oni podczas takich cyklów koncertowych i festiwali, jak m.in. „Warszawska Jesień”, „Warsaw Music Week", "Strefa Monotype“, "Jazz na Starówce“, Międzynarodowy Festiwal Pianistów Jazzowych w Kaliszu, CoCArt Festival Torun i również w renomowanych salach koncertowych takich instytucji, jak Filharmonii Narodowej, filharmonii w Gdańsku, Kielcach, Łodzi i Lublinie, na Zamku Królewskim w Warszawie oraz w Polskim Radiu ${ }^{16}$.

Od stycznia 2000 roku do końca 2011 roku odbywały się w austriackim forum kultury w Warszawie we współpracy z Uniwersytetem Muzycznym Fryderyka Chopina w Warszawie raz w miesiącu (z przerwą na lato) koncerty kameralne, przeważnie ze współczesnym austriackim repertuarem, w wykonaniu młodych polskich muzyków, studentów i absolwentów Warszawskiego Uniwersytetu Muzycznego ${ }^{17}$.

W roku 2004 austriackie forum kultury rozpoczęło współpracę z Międzynarodowym Festiwalem Muzyki Współczesnej, „Warszawska Jesień" opartym na młodych wykonawcach, laureatach cyklu, którzy pracują pod dyrekcją dyrygenta zaproszonego przez "Warszawską Jesień" i po okresie prób wykonują koncert w ramach festiwalu.

Kolejnym wydarzeniem cyklicznym są od dwóch lat spotkania pod hasłem „Harmonie i hałasy - spotkania z nową muzyką” jest to poznawanie współczesnej twórczości poprzez aktywne uczestnictwo w przygotowaniu

dziesiąt nazwisk niemieckojęzycznych twórców. http://austria.org.pl/new/de/literatura/ autorzy.php [dostęp: 21.01.2014]

16 Wydarzenie muzyczne, http://www.austria.org.pl/NEW/PL/muzyka.php [dostęp: 21.01.2014]

17 Przy tej okazji laureatom były wręczone cenne nagrody związane z ich przyszłym zawodem, jak n. p. stypendia umożliwiające udział w letnich kursach mistrzowskich w Austrii, zaproszenia na koncerty, bony nutowe, ufundowane przez sponsorów AFK: kraje związkowe Oberösterreich, Niederösterreich i Vorarlberg, Kulturkontakt Austria, Internationale Musitage Bad Leonfelden, Carinthischer Sommer, Grazer Konzertagentur, Internationale Sommerakademie Bernried, Internationale Sommerakademie Prag-Wien-Budapest, Polski Instytut w Wiedniu, Vereinigte Volksbanken Baden-Mödling-Liesing, wydawnictwo muzyczne Doblinger, Innviertler Gitarreseminar, Prezydent m. st. Warszawy, Austriacki Konsulat Generalny w Krakowie, Austriacki Konsulat Honorowy w Gdyni, Lubelskie Towarzystwo Gitarowe, Akademia Muzyczna im. F. Chopina w Warszawie oraz Österreich-Institut Warschau. 
koncertów. W projekcie, obok znanych wykonawców muzyki współczesnej, bierze udział młodzież ze szkół muzycznych i ogólnokształcących. Przed każdym z koncertów cyklu odbywały się warsztaty, na których młodzież, na podstawie dzieł ważnych w historii nowszej muzyki, opracowała jego elementy - zarówno muzyczne, jak i odnoszące się do szerszego kontekstu kultury ${ }^{18}$. Prezentacje dokonań młodzieży stworzyły oprawę koncertu z utworami będącymi tematem warsztatów. To ważny krok w kierunku edukowania nowej publiczności Forum i wychowywania młodych ludzi do udziału w kulturze ${ }^{19}$.

Działalność AFK w dziedzinie propagowania dramatu i sztuki teatralnej przyniosły wymierne efekty $w$ postaci popularności sztuk austriackich dramaturgów. W latach 2004-2009 prowadzono swoisty przegląd obecności austriackich tekstów na polskich scenach. Forum proponuje również projekty multimedialne i występy taneczne, przedstawienia kabaretowe i warsztatowe dla młodych polskich aktorów ${ }^{20}$.

Na płaszczyźnie sztuk wizualnych sporo się zmieniło od momentu zmiany siedziby AFK. Od stycznia 2012 roku otwarto nowy rozdział w działalności Galerii Austriackiej. Pierwszy projekt Jacka Malinowskiego, który w 2013 roku objął funkcję kuratora i koordynatora, próbuje odnieść się do dotychczasowego profilu galerii, a także przedefiniować go. Koncentrując się na formule „forum" - miejsca, w którym różnice spotykają się by stać się podobieństwami - Galeria Austriacka będzie zapraszać artystów austriackich oraz artystów polskich i międzynarodowych, by znaleźć dla nich wspólny kontekst i pokazać możliwość konstruktywnego dialogu. Jednym $\mathrm{z}$ ostatnich działań była prezentowana $\mathrm{w}$ lutym 2014 roku wystawa biograficzna - „Gustav Klimt - prekursor modernizmu", ciesząca się dużą popularnością ${ }^{21}$.

Olbrzymie zasługi ma również AFK w dziedzinie propagowania nauki, konferencje, sympozja, wykłady i prelekcje z uznanymi history-

18 Wśród najnowszych projektów muzycznych, w których uczestniczyło Forum był 8 Festiwal Kultury Świata; http://www.festiwalkulturswiata.pl/ [dostęp21.01.2014]

19 Na temat poszczególnych koncertów http://www.austria.org.pl/NEW/PL/muzyka/ harmonie_halasy.php [dostęp 21.01.2014]

20 Wśród projektów multimedialnych wymienić można choćby: muzyczno-teatralny projekt "Suma z zer" autorstwa Konrada Rennerta i Burkharda Stangla swoją premierę miał w październiku 2005 roku na zamówienie MAK (Muzeum Sztuki Użytkowej) w Wiedniu. Projekt poświęcony jest zagadnieniu pominięcia, porażek i wypierania rozliczeń historii XX wieku i nazizmu. Z jednej strony „Suma z zer“ skupia się na szczególnej sytuacji Austrii, a z drugiej - na wszystkich pytaniach wynikających z działalności współczesnych ruchów politycznych na całym świecie.

${ }_{21}$ Galeria istnieje w siedzibie AFK już od 1999 roku i prezentuje dokonania twórców austriackich, polskich i środkowoeuropejskich. Wśród osób wystawiających w AFK znaleźli się min. Heinz Cibulka, Paul Divjak, Gerhard Gepp, Lisa Huber, Zygmunt Januszewski, Grzegorz Klaman, Peter Steiner, Ingeborg Strobl, maja Vukoje. 
kami, socjologami, filozofami weszły już do kanonu działalności tej instytucji. Spośród najważniejszych wydarzeń ostatnich lat odnoszących się do płaszczyzny badań wymienić można choćby: Konferencja z 2011 roku - „Zachodnie Bałkany i rozszerzenie Unii Europejskiej: w poszukiwaniu nowego paradygmatu”, ,Ekonomia polityczna społecznej kreatywności. Praca i wartość we współczesnym kapitalizmie" - konferencja z 2011 roku organizowana wespół z Fundacją Bęc Zmiana, Forum przeciw wykluczeniu osób chorujących psychicznie, zorganizowane wespół z Uniwersytetem Warszawskim w 2012 roku, Sympozjum Triest - Skrzyżowanie kultur w Europie Środkowo-Wschodniej, organizowane wespół z instytucjami kultury Włoch i Słowenii w 2013 roku, Międzynarodową konferencję naukową pt. „Pamięć, kultura i religia” poświęconą zagadnieniom na styku nauk społecznych oraz teologii z $2013^{22}$.

Działania na rzecz austriacko-polskich badań historycznych, społecznych i politycznych zawierają długa listę przedsięwzięć, w których partycypowało Forum. Mają one decydujące znaczenie dla prezentowania osiągnięć i promocji młodych, zdolnych twórców i badaczy. Stanowią również bazę do współpracy elit obydwu państw, grunt o solidnych podstawach kulturowych i społecznych.

AFK udziela również informacji na temat możliwości podjęcia studiów w Austrii czy uzyskania stypendium. Obecnie proponowane są trzy rodzaje stypendiów: Ernst Mach - Stypendium, Franz Werfel-Stipendium für junge Universitätslehrer der deutschen Sprache und österreichischen Literatur i Richard Plaschka-Stipendienprogramm, przeznaczone dla młodych pracowników uniwersyteckich w dziedzinie historii, których zakres badawczy i dydaktyczny koncentruje się na historii Austrii ${ }^{23}$.

Wśród stałych partnerów Austriackiego Forum Kultury wymienić należy: Muzeum Historii Żydów Polskich, Teatr Kamienica, Uniwersytet Warszawski, Uniwersytet Jagielloński, Uniwersytet Wrocławski, Goethe Insitut czy European Union National Instutute for Culture.

\section{Działalność Austriackie Forum Kultury w nowych mediach}

Dla współczesnych odbiorców kultury Internet jest często głównym medium pozyskiwania informacji na temat ważnych wydarzeń, imprez, czy uroczystości ${ }^{24}$. Nie podobna dziś prowadzić instytucji bez jego udziału

22 Przegląd wydarzeń naukowych organizowanych lub współorganizowanych przez AFK - http://www.austria.org.pl/NEW/PL/nauka.php [dostęp 21.01.2013]

${ }^{23}$ Informacja na temat stypendiów http://www.austria.org.pl/NEW/PL/studia/stypendia.php [dostęp 21.01.2014]

${ }_{24}$ Młodzi i media. Nowe media a uczestnictwo w kulturze. http://www.swps.pl/ima- 
w nowych mediach. Zespół AFK od lat dba o to, aby Forum było widoczne i obecne $\mathrm{w}$ przestrzeni cyfrowej, także $\mathrm{w}$ zyskujących na znaczeniu mediach społecznościowych. Na jednym z najpopularniejszych portali społecznościowych - Facebook założono profil AFK w 2009 roku. Wówczas portal ten zaczynał zdobywać popularność wśród młodych Polaków. Regularnie informowano o wydarzeniach mających miejsce w siedzibie Forum, lub przygotowywanych wspólnie $\mathrm{z}$ innymi instytucjami. $\mathrm{Z}$ racji szerokiego spektrum zainteresowań i dużej liczby imprez ograniczano wpisy do jednego na dwa, trzy dni. Na jednym z pierwszych wydarzeń promowanych poprzez Facebook - „Ventzky. Dzieci sprawców, dzieci ofiar" zaproszono ponad 800 osób. Jest to duża grupa biorąc pod uwagę tematykę i miejsce spotkania (Dom Spotkań z historią w Warszawie). Od początku podawano informacje również w postach niemieckojęzycznych. W 2011 roku sporo miejsca poświecono akcji literacko - teatralnej: „Czytam gdzie indziej”, propagującej czytelnictwo. Ponadto często zwracano uwagę na konkursy: piosenki niemieckojęzycznej, literacki, na esej o tematyce polityczno-historycznej.

Obecne media zachęcają do interakcji z odbiorcami, publicznością. Większe możliwości techniczne pomagają wymieniać nie tylko informacje, opinie, oceny, lecz również pliki na których można odtworzyć zapis spotkania, bądź koncertu i tym samym zachęcić do dalszej współpracy ${ }^{25}$. Widać w tym zakresie większą wymianę pomiędzy nie tylko odbiorcami kultury, lecz również samymi instytucjami wspólnie poszukującymi adresatów. Austriackie Forum Kultury ma w tym względzie olbrzymie doświadczenia i staje się dzięki temu kopalnią wiedzy i przykładem budowania wieloletniej współpracy i partnerstwa w projektach międzykulturowych.

Forum wykorzystuje również inne kanały nowych mediów jak choćby YoTube i Wikipedię ${ }^{26}$. Dzięki krótkim filmom promocyjnym, można obejrzeć na kanale YoTube film z otwarcia nowej siedziby AFK przy ulicy Próżnej 7/9, czy zwiastuny zapowiadanych uroczystości ${ }^{27}$. Zaznaczyć jed-

ges/stories/dokumenty/RAPORT_SWPS_mlodzi_i_media.pdf [dostęp 21.01.2014]

${ }^{25}$ Fanpage AFK - https://www.facebook.com/pages/Austriackie-Forum-Kultury [dostęp: 21.01.2014]

${ }^{26}$ Polska edycja portalu Wikipedia zawiera jedynie krótki wpis na temat działalności Forum i linki do strony Ambasady w Warszawie http://pl.wikipedia.org/wiki/Austriackie_ Forum_Kultury_w_Warszawie [dostęp 21.01.2014]

${ }_{27}$ Otwarcie nowej siedziby Forum http://www.youtube.com/watch?v=qDNqp7Wwc8A [dostęp 21.01.2014]

W niewielkim stopniu AFK korzysta z promocji na Twitterze. Dzięki sympatykom Austrii wymieniane są wydarzenia realizowane w ostatnich latach. W sumie jest to kilkanaście wpisów. 
nak należy, że podczas promocji wydarzeń wykorzystuje się raczej tradycyjne metody: programy w formie książeczek, dostępne w plikach pdf, czy newsletter. Wykonanie tych materiałów pod względem graficznym i edycyjnym było zawsze na najwyższym poziomie ${ }^{28}$.

\section{Udział młodych w pracach i projektach Austriackiego Forum Kultury}

AFK nie zaniedbuje także młodych odbiorców kultury. Angażuje do współpracy dzieci i młodzież w różnych grupach wiekowych, proponując poza spotkaniami tematycznymi, możliwość wymiany poglądów czy pogłębienia nauki języka. Warto zwrócić uwagę, iż w świetle najnowszych statystyk młodzi ludzie stanowią grupę najchętniej uczestniczącą w kulturze, a także przeznaczającą na kulturę największą ilość swych miesięcznych dochodów ${ }^{29}$.

Od roku 2000 regularnie odbywają się koncerty z cyklu „Muzyczne forum młodych", które poświęcone są austriackiej muzyce współczesnej. Od 2005 roku istnieje biblioteka dziecięca, która przeznaczona jest dla najmłodszej publiczności.

Dzięki programowi Artist-in-residence, tworzonym wspólnie z landem Salzburg i miastem Wiedniem, trójka artystek i artystów czy pisarek i pisarzy rocznie może korzystać z miesięcznego pobytu rezydencyjnego w Warszawie, by na koniec zaprezentować swoje prace ${ }^{30}$.

Wielkim przedsięwzięciem była w listopadzie 2011 roku organizacja konferencji: „More Europe - what role can culture play in and outside the EU?" w Cetrum im. M. Kopernika, w którym uczestniczyło kilkuset młodych ludzi z całej Europy. Spotkania „More Europe“ odbywają się regularnie $\mathrm{w}$ różnych stolicach starego kontynentu. AFK uczestniczyło w organizacji spotkania w Warszawie i tym samym w największym kraju spośród tak zwanych „nowych członków“ UE. Zwrócono wówczas uwagę na fakt, iż Polska, aktywnie współpracuje w dziedzinie kultury z krajami spoza Unii, zwłaszcza z państwami Partnerstwa Wschodniego, pełni rolę „mostu“ pomiędzy Zachodem a Wschodem, także w obszarze polityki i gospodarki, kładąc jednocześnie szczególny nacisk na wzmocnienie

${ }_{28}$ Program na styczeń luty 2014 w wersji elektronicznej http://www.austria.org.pl/ archiwum/program.pdf [dostęp 21.01.2014]

${ }_{29}$ Badania pochodzą z raportu opublikowanego przez Główny Urząd Statystyczny w 2012 roku. http://www.stat.gov.pl/gus/5840_1741_PLK_HTML.htm [dostęp 21.01.2014]

30 Oficjalna Strona Internetowa Forum Kultury Austriackiej w Warszawie, http:// www.austria.org.pl/NEW/PL/onas.php 18.11.2012. 
społeczeństwa obywatelskiego przez kulturę. Debata dotyczyła głównie sposobu, w jaki kultura może wspierać budowę europejskiej tożsamości kulturowej w oparciu o społeczeństwo obywatelskie wewnątrz i na zewnątrz UE; struktur do tego potrzebnych; a także sposobu, w jaki artyści $i$ artystki oraz organizacje pozarządowe spoza UE, widzą te kwestie ${ }^{31}$.

\section{Efekty współpracy i skutki wsparcia Forum dla Polski}

W partii wniosków należy zwrócić uwagę na cele działań AFK zawarte w słowach: „Przedstawiamy obraz nowoczesnej Austrii jako godnego zaufania partnera w Unii Europejskiej, w partnerstwie regionalnym, w stosunkach dwustronnych i w gremiach międzynarodowych" ${ }^{32}$. W świetle dokonań Forum, choćby z ostatnich kilku lat należy przyjąć, że zadania te są stale i z sukcesem realizowane. Bilans jednego roku - 2012 zamyka się na organizacji blisko 300 projektów z 246 partnerami - muzeami, galeriami, teatrami, NGO, wydawnictwami, redakcjami i uczelniami wyższy$\mathrm{mi}^{33}$. To nie tylko prezentacja twórczości najwyższej próby, to inspiracje dla polskich artystów, mecenasów, ludzi kultury i elit politycznych. Podczas otwarcia nowej siedziby AFK w czerwcu 2013 roku gość honorowy - minister Władysław Bartoszewski z dumą wymieniał wspólne doświadczeniach w budowaniu demokracji europejskiej. Warto zwrócić uwagę, iż obecnie Austria i Polska wspólnie pracują nad tworzeniem nowych zasad życia w integrującej się Europie i mają najlepsze jak dotąd możliwości rozwoju wzajemnych relacji. Globalizacja stwarza nowe wyzwania dla kultury wysokiej i tradycyjnej. AFK daje często dobry przykład jak najbardziej istotne elementy kultury narodowej zachować przed degradacją czy zapomnieniem. Działania zmierzające do promocji młodych artystów, programy stypendialne, organizacja koncertów to również inspiracje dla polskich władz w jaki sposób warto z sukcesem promować polską kulturę w Europie. Forum pomaga w tym względzie włączając polskie instytucje kultury i nauki do własnych przedsięwzięć. Warto zwrócić uwagę na fakt,

${ }^{31}$ Relacje z Kongresu dostępne są na stronie: http://ninateka.pl/film/more-europe19-listopada-2012-warszawa [dostęp 21.01.2014]

${ }_{32}$ Cytat za Austriackim Forum Kultury, http://www.austria.org.pl/NEW/PL/onas. php, [dostęp 21.01.2013]

${ }_{33}$ R. Wolny, Modele zachowań młodych konsumentów na rynku usług w dziedzinie kultury, [w:] Marketing kultury. Nowe wyzwania oraz nowe kierunki działania, pod red. T. Domańskiego, Łódź 2008, s. 37-47, Por. G. Prawelska-Skrzypek, Regionalne zróżnicowanie polityki kulturalnej polskich miast, [w:] Instytucje kultury w czasach kryzysu, pod red. J. Sójka, D. Kliszewski, P. Landsberg, M. Popławski, Poznań 2009. 
że sukcesy jakie odnosi AFK wynikają z dużej ilości środków przeznaczonych na promocję twórczości austriackiej poza granicami państwa, lecz również z zakresu wprowadzania i ulepszania działań instytucjonalnych i prawnych odnoszących się do roli kultury w relacjach dwustronnych i międzynarodowych ${ }^{34}$. Należy tylko życzyć sobie, aby w przyszłości strona austriacka zechciała podtrzymać współpracę w dziedzinie wymiany kulturowej, jaką nieprzerwanie od kilkudziesięciu lat realizuje w Polsce poprzez swoją placówkę na ulicy Próżnej, a także by strona polska potrafiła zaadaptować austriacki wzór do promocji własnego dziedzictwa.

\section{Zusammenfassung}

\section{DAS ÖSTERREICHISCHE KULTURFORUM WARSCHAU UND DIE MODERNE ZUSAMMENARBEIT ZWISCHEN POLEN UND ÖSTERREICH}

Das Österreichische Kulturforum Warschau/Austriackie Forum Kultury (afk) wurde 1965 als erstes Kulturinstitut hinter dem Eisernen Vorhang gegründet und erfüllt seitdem seine Hauptrolle als offenes Zentrum der Begegnung mit polnischen Kunst- und Kulturschaffenden sowie dem polnischen Publikum. Es bietet nicht nur exzellente Räumlichkeiten in bester Lage, sondern ist auch dank seiner besonders prominenten historischen Rolle in der Zeit des Kommunismus vor 1989 als "Fenster des Westens" weiterhin eine renommierte Institution mit einem dichten und aktuellen Kontaktnetz zur innovativen polnischen Szene. Das Ziel dieser Arbeit ist, die Zusammenarbeit zwischen Polen und Österreich von 2001 bis $2013 \mathrm{zu}$ analysieren. Wichtige Fragen sind: auf welche Art und Weise zieht das afk Nutzen aus den in der Vergangenheit ausarbeiteten anderen Foren, Institutionen, Lösungen, die die Promotion der Kultur in Österreich unterstütze und wie beurteilen die Zusammenarbeit afk mit den polnischen Kulturinstitutionen? Sie werden einen Überblick über die kulturelle Polnisch-österreichischen Kontakte. Diplomatische Beziehungen werden als politische Kontakte und bilden eine „Brücke” zwischen Ländern. Das Österreichische Kulturforum Warschau möchte einen signifikanten Beitrag dazu leisten und bedankt sich bei allen polnischen, österreichischen und internationalen Partnerinstitutionen für die Zusammenarbeit.

${ }^{34}$ Zob. A. Burka, Co pozostało z okna na Zachód, op. cit., s. 192. Por. Strategie dla kultury. Kultura dla rozwoju. Zarządzanie strategiczne instytucja kultury, pod red. M. Śliwy, Kraków 2011. 